\title{
Solid waste management in Mekong Delta
}

\author{
Quản lý chất thải rắn ở Đồng bằng Sông Cưu Long \\ Review paper
}

Nguyen, Xuan Hoang*; Le, Hoang Viet

College of Environment and Natural Resources, Can Tho University, 3/2 Str., Can Tho city, Vietnam

\begin{abstract}
Municipal solid waste (MSW) in Vietnam has been increasing quickly and became one of the most considered environmental problems in Mekong Delta (MD) region covering 13 provinces and municipalities in the south of Vietnam. With a considerably large amount of MSW, the region produces about $5 \%$ of the total amount of MSW of the country. The collection rate of solid waste is about quite high $(65-72 \%)$ in the cities and rather low (about $40-55 \%)$ in the rural areas, with a high content in organic matter (about $60-85 \%$ ). The climate of MD can be characterized as tropical and monsoonal with a high rate of humidity and a strong impact of flooding. Like other regions too, the MSW collection and treatment system is still underdeveloped and rudimentary, with disposal sites being the sole dumping method of the unsorted MSW remaining untreated by any mechanical and biological pre-treatment steps. Within this paper, the current treatment, management and operation of MSW systems are introduced, as well as the identification of advantages and disadvantages, environmental impacts, potential risks of the MSW system within the impact of global climate change. The situation of MSW treatment and management is correlated with the climate change impact and the integrated solid waste management is introduced as a new approach for adapting the environmental protection awareness by considering the climate change for the longterm sustainable development orientation.
\end{abstract}

Sụ gia tăng chất thải rắn ở các đô thị Việt Nam ngày càng nhanh và chất thải rắn đang là một trong nhũ̃ng vấn đề môi trừng được quan tâm hàng đầu. Đồng bằng Sông Cửu Long (ĐBSCL) nơi có đến 13 tỉnh và thành phố nằm ở phía Nam Việt Nam. Với luợng chất thải không nhỏ, chiếm khoảng $5 \%$ tổng luợng chất thải rắn sinh hoạt của quốc gia. Tỷ lệ thu gom chất thải rắn thấp, chiếm khoảng 65 - $72 \%$ ở thành thị, tỷ lệ này ở nông thôn thấp 40 - 55\%, chất thải có hàm luợng hũu co cao chiếm khoảng 60 - 85\%. Khí hậu nhiệt đới gió mùa với độ ẩm không khí cao và chịu ảnh hưởng lớn của lũ lụt hàng năm. Cũng nhu các khu vục khác, hệ thống thu gom và xủ lý rác thải ở khu vục ĐBSCL còn rất thô so và lạc hậu, bãi rác là nơ duy nhất tiếp nhận trục tiếp hổn hợp rác thải không phân loại và qua bất kỳ công đoạn tiền xủ lý nào. Trong phạm vi bài viết này, chúng tôi giới thiệu hoạt động vận hành hệ thống quản lý và xủ lý rác đô thị trong khu vưc đồng thời phân tích các thuận lợi và bất lợi, cũng nhu các tác động môi truờng, nhũng rủi ro tiềm ẩn trong điều kiện ảnh hương của biến đổi khí hậu toàn cầu - khu vực ĐBSCL là nơi chịu ảnh huởng nặng nề nhất. Tình hình quản lý và xủ lý rác được cân nhắc trong điều kiện tác động của biến đổi khi hậu, đồng thời quản lý tổng hợp rác thải cũng được đề xuất nhu một các tiếp cận mới nhằm đáp úng nhiệm vu bảo vệ môi truờng trong điều kiện biến đổi khi hậu theo định huớng phát triển bền vĩng lâu dài.

Keywords: municipal solid waste management, waste collection, disposal, Mekong Delta

\section{Introduction}

As urbanization and economic development increase in Vietnam, nowhere is the impact more obvious than in society's "detritus," or solid waste. The fast increasing of municipal solid waste (MSW) quantity and the generation rate in the region have generated potential challenges to the management of MSW in urban areas. Nowadays,
MSW represents one of the most concerned environmental problems in the Vietnamese cities (Pham, 2007).

Mekong Delta comprises 12 provinces and one city with municipality status: the provinces Long An, Tien Giang, Vinh Long, Ben Tre, Dong Thap, Tra Vinh, Hau Giang, Bac Lieu, Soc Trang, An Giang, Kien Giang, Ca Mau, and Can Tho city. With a land area of $39,712 \mathrm{~km}^{2}$, the Mekong Delta accounts for $12.1 \%$ of the whole country 
area. The Mekong Delta is located in the middle of the dynamic socio-economic development region and near to the southern key economic zone - one of the most dynamic economic development zones in Vietnam.

The population is about 17.3 million people (2006 estimation), equivalent to $28 \%$ of the whole country population (CIA Factbook, 2010). The region has an agricultural output accounting for $50 \%$, food production for $90 \%$ and aquaculture products for $70 \%$ of the nation output (Nguyen and Nguyen, 2009). Most of the region is located in a very low-elevation area (below $+2.0 \mathrm{~m}$ above sea level), except some hilly areas in An Giang and Kien Giang provinces. The high water level of the East Sea's tide (rising up to $+2.14 \mathrm{~m}$ ) is obviously affecting the Mekong Delta basin along the main rivers. According to the IPCC interim recommendation (IPCC, 2007), in case of a sea level rise of up to $1 \mathrm{~m}$, an area of 15,000 to $20,000 \mathrm{~km}^{2}$ in the Mekong Delta would be flooded, resulting in millions of people having to move their housings and with their agricultural production being seriously reduced (Nguyen and Nguyen, 2009). A high risk of damage of the economy and food security is obvious if the effect of sea level rising on the Delta is not properly studied and understood for preparing a strategic action plan.

The fast urban development implied irrational planning for residential and industrial areas, disposal sites etc. and accelerated even more the existing environmental problems in the region. In addition, the future increase in flooding events will provide even more difficulties for the treatment and management of MSW, which are still underdeveloped today and unable to cope with such challenges in the future.

\section{MSW generation and management}

\subsection{MSW generation}

The annual amount of waste generated in Vietnam approximates 15 million tons, of which the MSW accounts for about $80 \%$ with most of it being disposed in landfills or open dumpsites. The remaining fractions are industrial waste $(17 \%)$, healthcare waste from hospitals $(0.14 \%)$ and others (MONRE, 2010). The per capita MSW generation rate varies from province to province. In Mekong Delta, the average quantity of MSW is rather low in comparison to those of big cities in Vietnam. The generation rate varies from $0.3 \mathrm{~kg} /$ capita-day for the whole province (including rural areas) to $1.2 \mathrm{~kg} /$ capita-day for the urban area only (MONRE, 2010).

Different MSW compositions were reported among the big cities and the small cities in Vietnam. Most of the available data on MSW is collected from big cities, very little or no data being available for suburban or rural areas (even for hazardous and healthcare waste). The total amount of MSW generation in Mekong Delta is about 600,000 tons annually, which amounts to approximately 1,645 tons per day. In comparison to the national MSW generation of about 35,100 tons per day, this accounts for about $5 \%$ of the total amount of MSW produced nationwide (MONRE, 2010). It is estimated that the average
MSW generation rate increases with about $10-16 \%$ yearly. It is predicted that the MSW, industrial waste and healthcare waste will be about 4,253, 310 and 41 tons per day in 2015 and about 5,514, 973, and 52 tons per day in 2020, respectively (MONRE, 2010).

The composition of MSW is also different between urban and rural areas. The hospital and industrial wastes are predicted to increase considerably in the key economic zone and in Mekong Delta (MONRE, 2010). The hazardous waste such as dry and wet batteries, electric waste and household chemical solvents and non-degradable waste (plastic, metal, and glass) were presented more and more in urban waste due to the fast development of industrialization and urbanization. There is a high percentage of organic matter $(54-87 \%)$ in the waste and also a diversified waste fraction (organic matter, paper, metal, glass, textile, plastic and rubber, ceramic and brick, hazardous and miscellaneous) that is characteristic for the MSW in the cities in Mekong Delta region (Table 1).

\subsection{MSW management system}

In the urban and partly in the suburban areas, the waste collection systems are rather efficient but in the other regions, the collection is improperly managed. In cities, the urban environment company URENCO Ltd. is responsible for the management of MSW. This company is responsible for the collection, transportation and treatment of MSW from all sources (MONRE, 2004). In addition, the private recycling centres are also sharing their role in the management and treatment of MSW in the cities. The typical components of the waste management system are as follows (see also Figure 2):

\subsubsection{Household waste}

In the residential areas, the MSW is collected in trash bins designed in different forms and with different sizes, colors etc. In general, the trash bins have volumes in the range of $5-100$ liters and are made of plastic, metal or even brick tanks or temporary containers (plastic bags, paper bags or boxes). The bins/bags are collected by the URENCO staff from the front of household or the curbside of the street.

\subsubsection{Commercial, hospital and industrial wastes}

Generally, the waste in Vietnam can be classified into three main categories: MSW, hazardous waste and preselective recyclable waste. The URENCO is normally responsible for collecting all kinds of waste in the urban areas. The industrial waste is collected by URENCO following the service contract with the firms. Besides, the hazardous waste is separately collected and treated by the waste treatment plant approved by the local Department of National Resources and Environment (DONRE). For the pre-selective recyclable waste, private recycling services unofficially collect and recycle these materials by their own. Moreover, the medical waste from hospitals is collected in special storage tanks of 120 liters with a special seal and logo on top.

\subsubsection{The street and market wastes}


The waste generated from urban streets, public places and squares, bus stations, and permanent / temporary markets is collected by the URENCO's collection services. This work has to be done daily by manual (broom) or mechanical means (sweeper vehicle).

\subsubsection{Transfer station}

Transfer stations are often used as places where local waste collection vehicles (handcarts) will unload their waste cargo prior to loading into larger vehicles (trucks, garbage compressors). However, a popular practice implies accumulating the waste on the urban roads, the socalled "meeting points" in the urban in Mekong Delta. The unloading/loading activities take place outdoor without any environmental protection measures. Some of the transfer stations are designed with automatic transporters and garbage compressors while others are poorly equipped, often only with steel containers or concrete tanks.

\subsubsection{Transportation means (vehicles)}

Handcarts with volume $0.6-1.5 \mathrm{~m}^{3}$ are used as local transportation vehicles that collect the generated waste at sources. These are then moved to the transfer stations or meeting points and there waste is unloaded and reloaded into larger vehicles such as forklift trucks, garbage compressors, specialized trucks, etc. for the shipment to the disposal site. The typical capacity of these vehicles is from 4 to 13 tons. In addition, waterway service vehicles are also used for the collection of floating waste on rivers and canals generated directly from trading activities (floating markets), ships or boats (see Figure 1).

Table 1. Typical composition of MSW in cities/provinces in Mekong Delta

\begin{tabular}{|c|c|c|c|c|c|c|c|c|c|}
\hline $\begin{array}{c}\text { City/ } \\
\text { province }\end{array}$ & $\begin{array}{c}\text { Organic } \\
\text { matter }\end{array}$ & Paper & Metal & Glass & Textile & $\begin{array}{l}\text { Plastic } \\
\text { and } \\
\text { rubber }\end{array}$ & $\begin{array}{c}\text { Ceramic } \\
\text { and brick }\end{array}$ & $\begin{array}{c}\text { Hazardous } \\
\text { waste }\end{array}$ & Others \\
\hline Can Tho & 79.65 & 2.79 & 0.70 & 1.52 & 1.86 & 9.57 & 3.10 & 0.03 & 0.76 \\
\hline $\mathrm{Ca} \mathrm{Mau}$ & 57.30 & 4.50 & 0.10 & 0.50 & 1.40 & 6.10 & 2.10 & - & 28.00 \\
\hline Soc Trang & 70.35 & 4.12 & 0.78 & 0.66 & 3.11 & 7.24 & 9.63 & - & 4.11 \\
\hline Tien Giang & 77.53 & 3.89 & 0.23 & 0.21 & - & 6.37 & 2.14 & 0.06 & 9.57 \\
\hline Long An & 76.30 & 5.10 & 0.37 & 0.70 & - & 13.63 & 2.68 & 0.15 & 4.08 \\
\hline Ben Tre & 73.85 & 6.50 & 1.75 & 0.85 & - & 5.20 & 1.60 & 0.3 & 9.95 \\
\hline Tra Vinh & 87.25 & 2.05 & 0.45 & - & - & 3.16 & 2.04 & - & 5.05 \\
\hline Vinh Long & 66.25 & 11.50 & 0.55 & 4.00 & 6.50 & 9.45 & 0.75 & - & 1.00 \\
\hline Bac Lieu & 53.34 & 4.51 & 4.59 & 4.91 & - & 4.44 & 10.81 & 2.78 & 14.62 \\
\hline Hau Giang & 82.60 & 1.80 & 0.40 & 0.90 & 1.50 & 5.70 & 1.60 & 4.00 & 1.50 \\
\hline Kien Giang & 72.52 & 6.38 & 1.27 & 1.64 & 1.29 & 7.69 & 7.49 & - & 1.72 \\
\hline Đong Thap & NA & NA & NA & NA & NA & NA & NA & NA & NA \\
\hline An Giang & NA & NA & NA & NA & NA & NA & NA & NA & NA \\
\hline
\end{tabular}

(Source: INVENT, 2009)

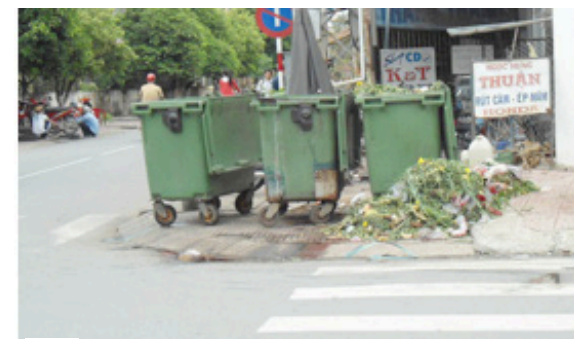

a)

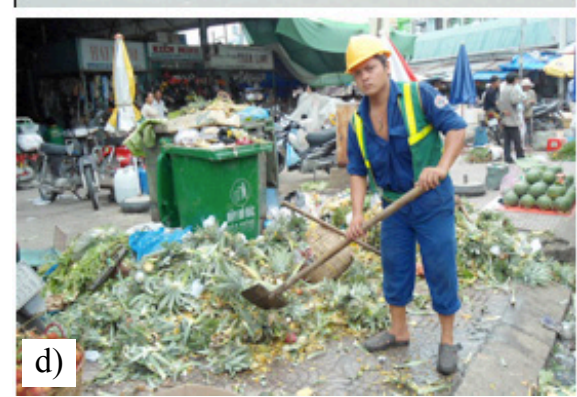

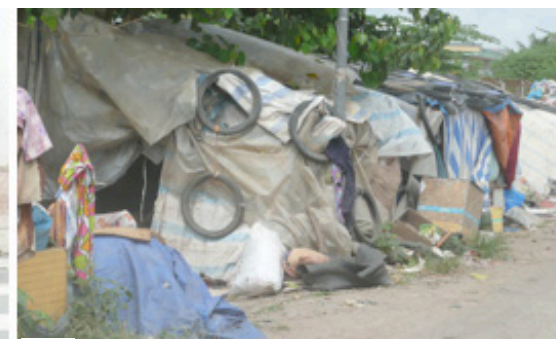

b)

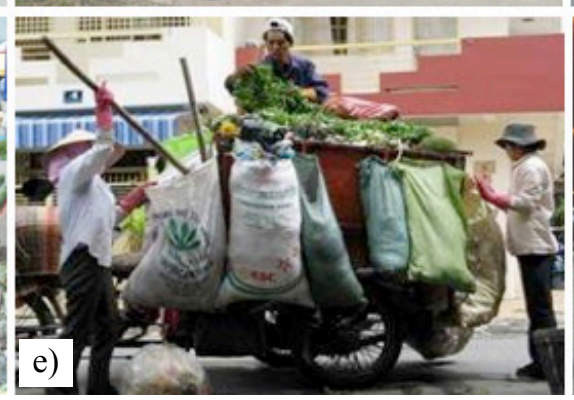



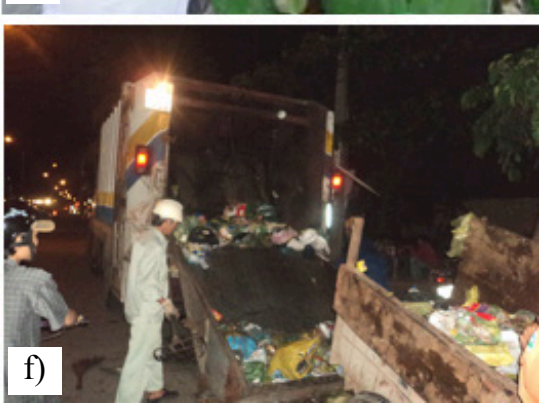

Figure 1. Waste collection activities at sources, transfer station, and transportation vehicles used in Mekong Delta region: a) plastic containers b) recycling centre c) garbage collection by boat d) waste collector in a market e) waste collection by handcarts f) "meeting points" on the street 


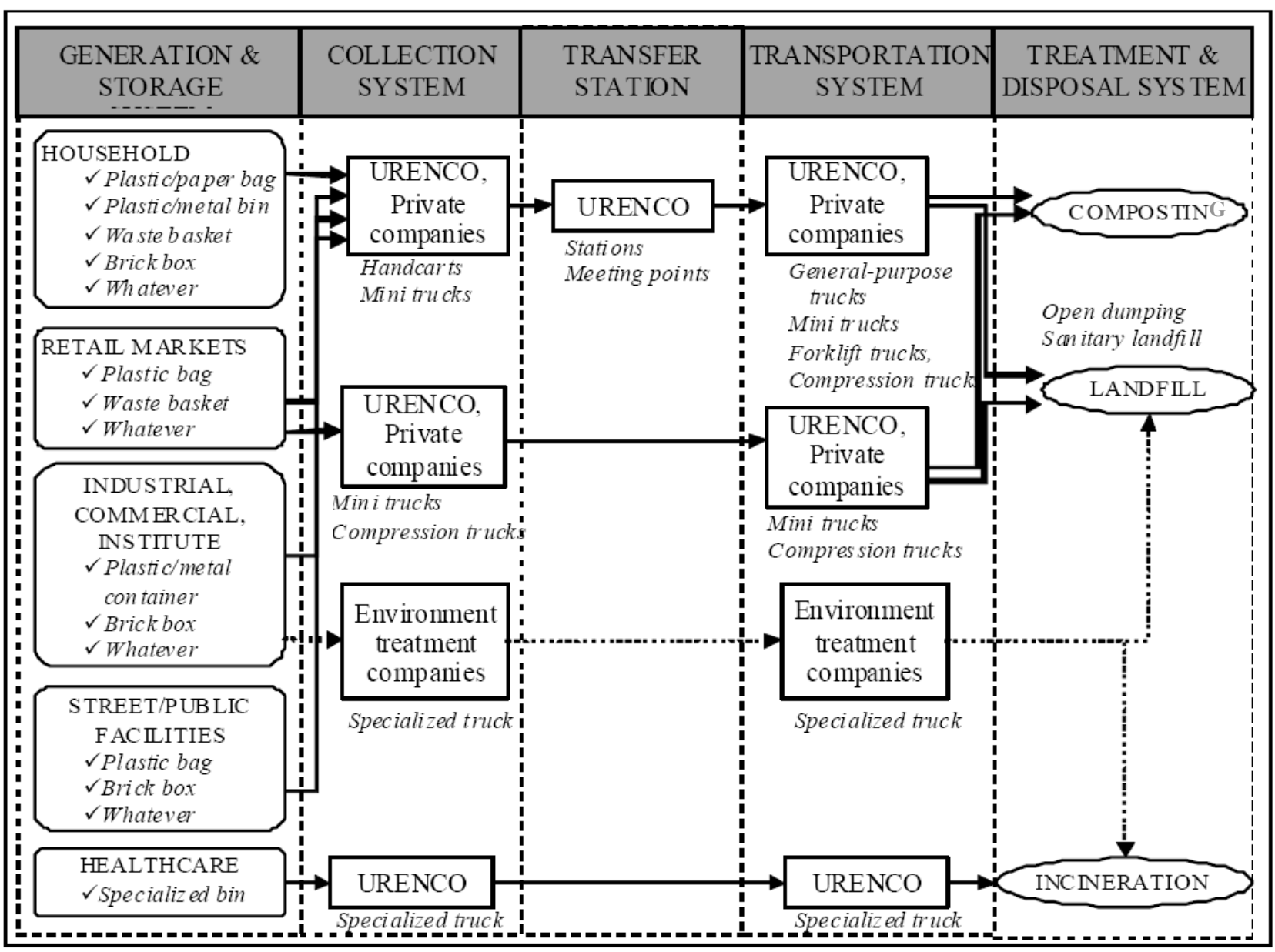

Figure 2. Flow diagram of typical solid waste management in Vietnam (Thanh, 2009)

\section{Institutional management structures and legal framework for MSW}

The Environmental Protection Law was introduced in 1994 and upgraded in 2005; however, the related environmental regulations and standards are not sufficient implemented. The Vietnamese Ministry of Natural Resources and Environment (MONRE) is the highest administrative organization under the government in the field of environmental management and policy issues. MONRE is the supreme institution responsible of the management, monitoring, and assessment of environmental protection within the nation.

In addition, five related ministries also share their roles in the waste management activities (see Figure 3). These ministries include the Ministry of Health (MOH), Ministry of Construction (MOC), Ministry of Planning and Investment (MPI), Ministry of Transportation (MOT), and Ministry of Industry (MOI). Moreover, the local governmental institutions at provincial and city level - the People's Committee (PC), the Department of Natural Resources and Environment (DONRE), and the Urban Environment Company (URENCO) - are directly involved in the management of MSW (Viet et al., 2009).

The local PC bears the responsibility for (i) the state administrative management, working as a coordinator in managing and operating environmental protection system together with the central authorities (ii) leading orienta- tion of the MSW management policy, project management (e.g. design, construction and super-vision, etc.) and (iii) investment and support of equipment and technologies for MSW treatment system.

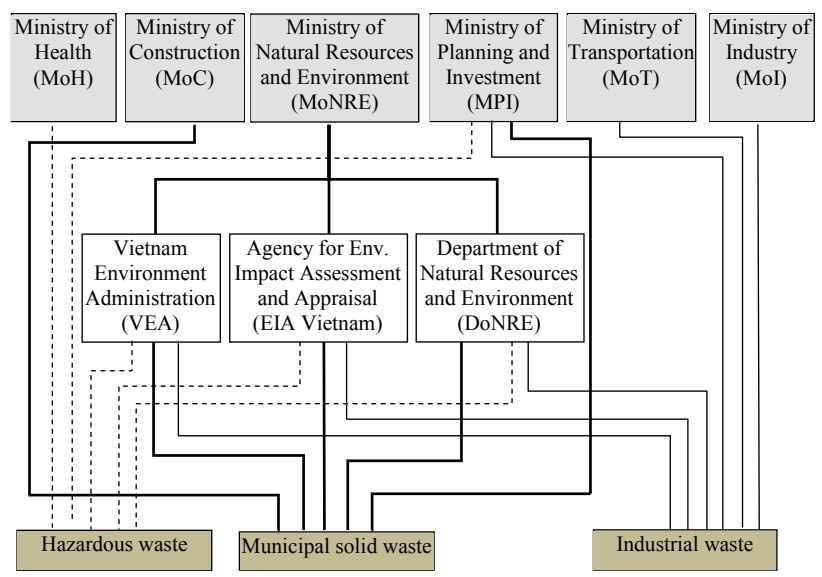

Figure 3. Institutional structure of waste management (Viet et al., 2009)

The DONRE is an institution at the provincial level directly subordinate under the MONRE that acts on the cooperation, support, and technical guidance. In addition, this institution administratively acts under the PC. The DONRE plays an important role in the waste management activities including environmental quality monitoring, management and implementation of environmental protection. 
URENCO is a company under DONRE's control or the local PC that is directly responsibility for the collection, transportation and treatment of MSW in the provinces/cities.

Regarding the legal framework of MSW management, the Vietnamese government issued a series of legal instruments for stimulating the environmental protection within the country. These legal frameworks include the environmental protection legislation, the solid and hazardous waste legislation, toxic substance legislation, medical waste legislation, legislation on recycling, legislation on waste management infrastructure facilities, fees and charges, related standard systems, and the international conventions (Viet et al., 2009). Apart from that, the Strategy for the Management of Solid Waste in Vietnam Cities and Industries (1999), the National Strategy for Environmental Protection (2003), and the National Strategy for Integrated Solid Waste Management until 2025 Vision Towards 2050 compose the legal framework for the implementation of environmental protection in the future.

\section{Treatment of MSW in Mekong Del- ta}

In general, the treatment of MSW in Mekong Delta includes composting, burning and incineration, and landfilling.

\subsection{Composting}

Composting represents the decomposition of organic wastes under controlled conditions to produce compost product that can be further used as soil conditioner or fertilizers. With a high organic matter content, the MSW in Mekong Delta's provinces has a great potential for composting (Byer et al. 2006). However, waste composting is not widely used in the region for a number of reasons including inadequate requirements of biological process such as poor feed stock or nutrient requirements, poor quality of output fertilizers, and even reduced potential market. Besides, the bio-products from old landfills that were biodegraded by natural process can be utilized as fertilizers. Presently, more private companies carried out their composting for the city's MSW with similar composting technologies at a small scale (see Figure 4). Another reason for making composting less attractive is the farmers' habit in using inorganic fertilizer instead of compost.

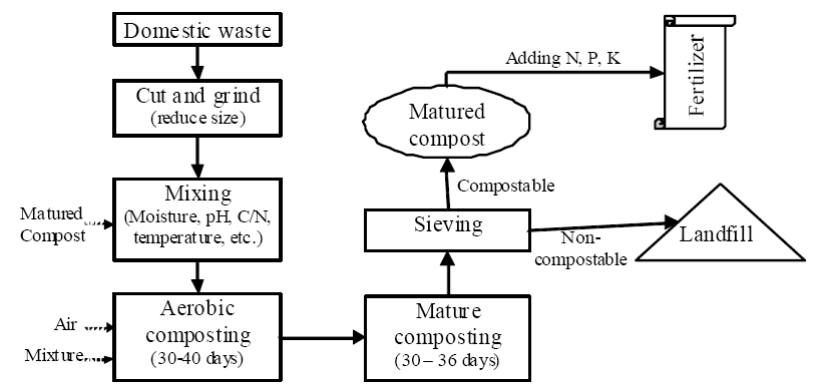

Figure 4. A typical composting system (Thanh, 2009)

\subsection{Burning and incineration}

Incineration is not a common practice in Vietnam, being rather applied for the medical waste in some hospitals so that it can be disposed to landfills. Moreover, Vietnam does not have the necessary technology to analyse dioxin concentrations emitted by the incinerators even this is regulated through technical standards for gas emissions (Dan and Viet, 2009). The existing small incinerators with capacities of 5 - 20 tons per day faced problems as they generally cannot meet the national standards for burning temperature and gas emission for avoiding dioxins and furans.

Open burning at landfill sites is an illegal practice, however it is sporadically done in some cities/provinces in dry season to reduce the volume of waste and to increase the capacity of disposal sites. The method is often practiced in rural areas where almost no interest is paid to the hazardous environmental emissions or toxic substances that can cause negative effects to the environment and human health.

\subsection{Landfilling}

Landfilling is the common disposal method for MSW in Vietnam as well as for some industrial waste and healthcare waste. In addition, there are no sanitary or engineered landfills in the region, most of disposal sites being in fact open landfills/open dump sites without any protection barriers for leachate and gas collection. Moreover, the low land with a high flooding impact and a high precipitation in the region make it more difficult for the treatment and management of MSW than the other region in Vietnam. For that reason, the landfilling poses a high potential risk of negative impact on the environment and the human health.

\subsection{Recycling}

Recycling and reuse is mainly done by the private sector (e.g. waste pickers, collectors, garbage truck helpers, scavengers, etc), and occurs along the waste stream from the generation to the final disposal step. The recyclable waste fractions can be collected at source (households, building, markets, etc), garbage storages, collection and transfer stations (meeting points), and at the dumpsites. However, no official system is in place therefore recycling in Vietnam can be called "unofficial recycling". The fractions collected include cardboard, plastics, newspapers, scrap paper, glass bottles, scrap metals, etc. After collection, these materials are sent to the recycling centres. According to VEM (MONRE, 2010), the recyclable fraction is rather high, for example about $15-19 \%$ of the total MSW at the landfill sites in Ho Chi Minh City.

\subsection{Solution for treatment and management of MSW in Mekong Delta in the future}

The management of MSW in the Mekong Delta is becoming more complicated due to the fast increase of MSW quantity and also the climate change effects. Some typical problems and limitations were identified together with the 
climate change impacts, the suggestions for integrated MSW management in the future being listed in Table 2.

The integrated solid waste management (ISWM) refers to a strategic initiative for the sustained management of solid waste as a new approach in Mekong Delta for managing the entire solid waste cycle, from collection, to recycling, to eventual disposal based on the concept of all aspects of waste management system (technical and non-technical).

Table 3. Problem identification and suggestion for MSW management in Mekong Delta

\begin{tabular}{|c|c|c|c|}
\hline $\begin{array}{l}\text { Tasks or } \\
\text { components }\end{array}$ & Problems and limitation & $\begin{array}{l}\text { Climate change } \\
\text { effects (flooding) }\end{array}$ & Suggestion \\
\hline $\begin{array}{l}\text { National policy and } \\
\text { legal framework }\end{array}$ & Weak and less effectiveness & & - To improve effective implementation \\
\hline Trash bin & $\begin{array}{l}\text { Improper, not enough in } \\
\text { some places }\end{array}$ & & $\begin{array}{l}\text {-To re-arrange the trash bin location } \\
\text { - To upgrade the foundation }\end{array}$ \\
\hline Infrastructure & $\begin{array}{l}\text { Low and incomplete infra- } \\
\text { structures }\end{array}$ & $\begin{array}{l}\text { Easily getting } \\
\text { flooded }\end{array}$ & $\begin{array}{l}\text { - Need to be re-constructed } \\
\text { - To make a higher foundation }\end{array}$ \\
\hline $\begin{array}{l}\text { Transfer and trans- } \\
\text { portation }\end{array}$ & $\begin{array}{l}\text { Not good transfer station, } \\
\text { less effective and weak } \\
\text { environmental protection }\end{array}$ & $\begin{array}{l}\text { Transfer and trans- } \\
\text { portation route can } \\
\text { be flooded }\end{array}$ & $\begin{array}{l}\text { - To design suitable transfer stations } \\
\text { for flooding area } \\
\text { - Transportation improvement }\end{array}$ \\
\hline $\begin{array}{l}\text { Intermediate treat- } \\
\text { ment }\end{array}$ & $\begin{array}{l}\text { Poor and less technical and } \\
\text { financial support for biolog- } \\
\text { ical treatment of high organ- } \\
\text { ic MSW }\end{array}$ & $\begin{array}{l}\text { Can be considered } \\
\text { for adapting cli- } \\
\text { mate change ef- } \\
\text { fects }\end{array}$ & $\begin{array}{l}\text { - Increase amount of MSW treatment } \\
\text { by intermediate } \\
\text { - Upgrade and develop biological } \\
\text { treatment for MSW (e.g. composting) } \\
\text { - Introduce thermal treatment and in- } \\
\text { cineration } \\
\text { - Introduce biogas/composting process } \\
\text { for sludge of sewage and septic tanks }\end{array}$ \\
\hline $\begin{array}{l}\text { Final treatment } \\
\text { (landfill) }\end{array}$ & $\begin{array}{l}\text { Not good environmental } \\
\text { protection (leachate, gas } \\
\text { emissions, etc.) }\end{array}$ & Can be flooded & $\begin{array}{l}\text { - Reduce the amount of MSW for dis- } \\
\text { posal } \\
\text { - Site selection needed } \\
\text { - Sanitary landfill design for flooded } \\
\text { areas }\end{array}$ \\
\hline $\begin{array}{l}\text { National encour- } \\
\text { agement or subsidy }\end{array}$ & Not enough & & $\begin{array}{l}\text { - Need a national financial and tech- } \\
\text { nical support }\end{array}$ \\
\hline $\begin{array}{l}\text { Public participation } \\
\text { and environmental } \\
\text { education }\end{array}$ & $\begin{array}{l}\text { Not good public participa- } \\
\text { tors } \\
\text { Weak environmental educa- } \\
\text { tion, especially for children }\end{array}$ & & $\begin{array}{l}\text { - Need to be developed } \\
\text { - Enhancing environmental education } \\
\text { for children (books, newspaper, tele- } \\
\text { vision, etc) }\end{array}$ \\
\hline $\begin{array}{l}\text { Integrated solid } \\
\text { waste management }\end{array}$ & Weak, initially introduction & $\begin{array}{l}\text { Can be considered } \\
\text { with an effect of } \\
\text { climate change }\end{array}$ & - Need to be applied soon \\
\hline
\end{tabular}

\section{Conclusions}

With the fast increasing of MSW and the climate change impact on Mekong Delta in the coming years, the high potential challenges and risks from improper solid waste management have to be recognized. Related issues on waste treatment and management need to be improved or developed, including policy and strategy development, waste management and treatment upgrading in consideration to the ISWM as a new approach. This was recognized in the National Strategy Plan for Integrated Management of Solid Waste up to 2025, Vision Towards 2050" (Decision No. 2149/QĐ-TTg from the Prime Minister).

\section{References}

[1] Byer P.H., Hoang C.P., Nguyen T.T.T., Chopra S., Maclaren V., and Haight M. 2006. Household, hotel and market waste audits for composting in Vietnam and Laos. Waste Manage. Res. 24:465-472
[2] CIA 2010. The World Factbook. (https://www.cia.gov/library/publications/the-worldfactbook/geos/vm.html, retrieved on 2011-11-27)

[3] INVENT 2009. Innovative Education Modules and Tools for the Environmental Sector, particularly in Integrated Waste Management. Handbook of INVENT project

[4] IPCC 2007. Climate change 2007: Impacts, adaption and vulnerability. Contribution of Working Group II to the Fourth Assessment Report of the Intergovernmental Panel on Climate Change. M.L. Parry, O.F. Canziani,, J.P. Palutikof, P.J. van der Linden and C.E. Hanson, Eds., Cambridge University Press. Cambridge, UK, 976 pp

[5] Le, H. V., Nguyen, V. C. N., Nguyen, X. H., Do, N. Q., Songkasiri, W., Stefan, C., Commins, T. 2009. Legal and institutional framework for solid waste management in Vietnam. As. J. Energy Env. 10(04):261-272 
[6] MONRE (Ministry of Natural Resources and Environment) 2004. Vietnam Environment Monitor 2004. Ha Noi

[7] MONRE (Ministry of Natural Resources and Environment) 2010. Vietnam Environment Monitor 2010. Ha Noi

[8] Nguyen, P. T., Yasuhiro, M., Takeshi, F. 2010. Household solid waste generation and characteristic in a Mekong Delta city. Journal of Environmental Management 91(11):2307-2321

[9] Nguyen, P. D., Nguyen, T. V. 2009. Status and strategies on solid waste management in Ho Chi Minh City. Int. J. Environment and Waste Management 4(3/4):412-421

[10] Pham S.L., 2007. Handling of solid waste in Vi- etnam. The $4^{\text {th }}$ Civil Engineering Conference in the Asian Region held by the Asian Civil Engineering Coordinating Council (ACECC) in Taipei 26-28 June, 2007

[11] Trinh C. V. 2011. Identification of Sea Level Rise Impacts on the Mekong Delta and Orientation of Adaptation Activities (http://www.vncold.vn/ Modules/CMS/Upload/13/Science/

TCVanEwv09 160509/identification\%20sea\%20lev el\%20rise $\% 20$ impacts\%20on\%20MK\%20delta_5apr il.pdf retrieved on 2011-11-27)

[12] UNEP 2009. Development integrated solid waste management plan: training manual. Volume 4. ISWM Plan. UNEP DTIE International Environmental Technology Centre, CTI/1140/JP 